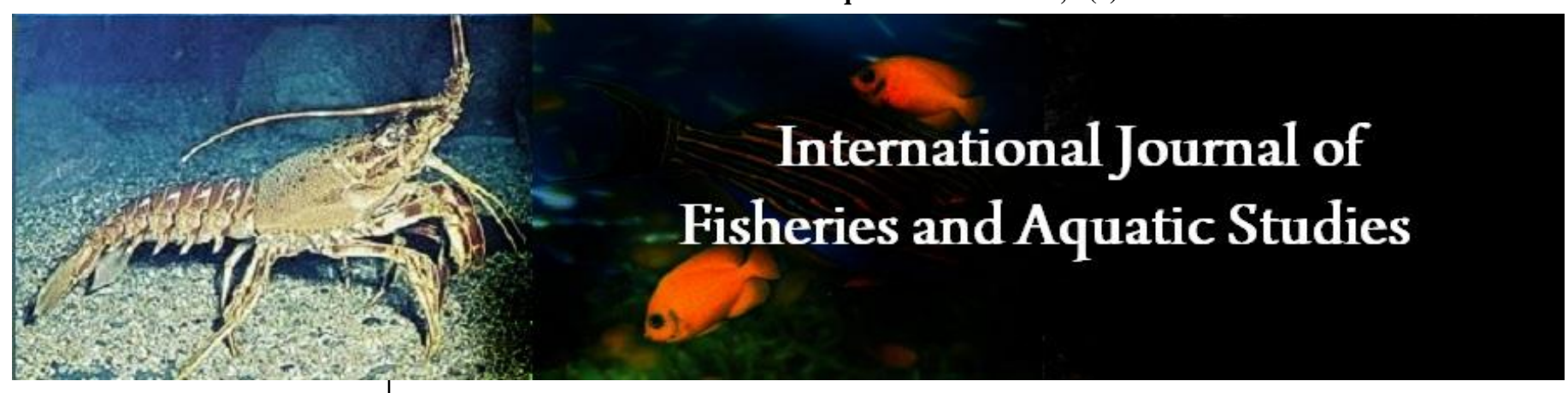

E-ISSN: 2347-5129

P-ISSN: 2394-0506

(ICV-Poland) Impact Value: 5.62

(GIF) Impact Factor: 0.549

IJFAS 2020; 8(4): 377-384

(C) 2020 IJFAS

www.fisheriesjournal.com

Received: 22-06-2020

Accepted: 26-07-2020

Bandla Seshagiri

Regional Research Centre,

ICAR-Central Institute of

Freshwater Aquaculture,

Poranki, Andhra Pradesh, India

MVS Nagireddy

Agriculture Mission, Amaravati,

Andhra Pradesh, India

V Ramachandra Raju

Delta Fish Farmers Welfare

Association, Eluru, Andhra

Pradesh, India

S Nagireddy

Nagarjuna Fisheries Trust,

Telaprolu, Andhra Pradesh,

India

PV Rangacharyulu

Regional Research Centre,

ICAR-Central Institute of

Freshwater Aquaculture,

Poranki, Andhra Pradesh, India

Ramesh Rathod

Regional Research Centre,

ICAR-Central Institute of

Freshwater Aquaculture,

Poranki, Andhra Pradesh, India

V Ratnaprakash

Krishi Vigyan Kendra,

Vinayashramam, Guntur,

Andhra Pradesh, India

Corresponding Author:

Bandla Seshagiri

Regional Research Centre,

ICAR-Central Institute of

Freshwater Aquaculture,

Poranki, Andhra Pradesh, India

\section{Impact of nationwide lockdown on freshwater aquaculture in Andhra Pradesh, India}

\author{
Bandla Seshagiri, MVS Nagireddy, V Ramachandra Raju, S Nagireddy, \\ PV Rangacharyulu, Ramesh Rathod and V Ratnaprakash
}

DOI: $\underline{\text { https://doi.org/10.22271/fish.2020.v8.i4e.2295 }}$

\begin{abstract}
Aquaculture has been recognized as instrumental in generating income and rural employment besides stimulating growth of a number of ancillary industries. It has increased manifold in Andhra Pradesh in recent times in comparison to agriculture as it brings more profit and requiring less labour per unit area. Outbreak of coronavirus has not only disrupted aquaculture activities but had impact on the farmers' economy. It affected stocking, pre and post harvesting activities due to prolonged lockdown. Paucity of labor, shortage of inputs, lack of transportation and decline in marketing has complicated the difficulties of aqua farmers. Fish transports have reduced by $85 \%$ in domestic markets. Leading urban fish markets in India are operating with less than $10 \%$ of workers. Hatchery operators skipped pre-monsoon breeding losing one-third of seed production. Farmers were incurring 10 to $18 \%$ losses on production cost. Most of the farm labour are migrant workers. Farm repairs and machine operations affected due to scarcity of manpower. Seed stocking delayed due to suspension of fish harvests. Although, government has exempted fisheries from lockdown, farming operations hampered due to difficulties in social distancing. Retail markets and livelihood of women fish vendors were severely affected. Overall nationwide lockdown imposed to check the spread of COVID-19 has delivered a blow on the morale of the aqua farmers as also affecting the Indian economy.
\end{abstract}

Keywords: Coronavirus, lockdown, aquaculture, fisheries, Andhra Pradesh

\section{Introduction}

Fisheries sector in India, has recorded higher growth rate than of the crop and livestock sectors and contributes to the livelihood of a large section of the economically underprivileged population of the country (Kumar et al., 2006) ${ }^{[1]}$. It has been recognized as instrumental in generating income and rural employment besides stimulating growth of a number of ancillary industries. Further, fisheries provide economical and nutritious food, besides being a foreign exchange earner to the exchequer (Ayyappan and Krishnan, 2004) ${ }^{[2]}$. Aquaculture has increased manifold in Andhra Pradesh in recent times in comparison to agriculture as it brings more profit than agriculture besides requiring less labour per unit area (Sushmakrishna et. al., 2019) ${ }^{[3]}$. Andhra Pradesh has been contributing to $25 \%$ to the fish production in India in recent years through an effective strategy in both coastal and freshwater aquaculture and marketing. The state has 5.17 lakh ha of freshwater ponds and tanks, $11,514 \mathrm{~km}$ of rivers and canals, 4.58 lakh ha of reservoirs and 150,000 ha of water areas suitable for coastal aquaculture. The inland fish production is 3.49 million tons (PIB, 2019; Srikanth, 2020) ${ }^{[4,5]}$ including 6.04 lakh ton of marine fish along with farmed shrimp in brackish waters (Keelery, 2019) ${ }^{[6]}$. Andhra Pradesh is achieving rapid progress in aquaculture with vast potential for the development of fish and prawn cultivation and sea food production. The fish and prawn production has 6.04 per cent share in the Gross State Domestic Production (GSDP) and providing direct employment to 14.5 lakh people (Ameen, 2018) ${ }^{[7]}$. Nationwide lockdown which was declared on account of COVID-19 would not have arrived at a worse time than ever for the aquaculture sector in Andhra Pradesh that contributes significantly to Gross State Domestic Production (Kumar, 2018) ${ }^{[8]}$. The present study emerged from the need for information as there is no existing data that to analyze the impact of lockdown on ongoing crop, harvest and post-harvest events in freshwater aquaculture in Andhra Pradesh 


\section{Methods and Methodology}

Current study was carried out conforming to procedures of online survey (Andrews et. al., 2003) ${ }^{[9]}$ in order to evaluate the impact of lockdown imposed in India on aquaculture activities in Andhra Pradesh due to pandemic, COVID-19. The methodology was split into actionable approaches. Only few number of questions used in this study which varied while relating to respondent as also depended on the objective underlying the survey (Evans and Mathur, 2005) [10]. Responses were obtained from 50 respondents hailing from three districts mentioned above. Cross section distribution of respondents who participated in this study included fish farmers (45\%), Hatchery owners (20\%), Farm workers (15\%), Fish Traders and Transporters (10\%), Retail sellers (10\%) and Feed Plants (5\%) as depicted in the form of pie-chart (Fig.1). Not more than four closed end questions were posed to each respondent in the present study in order to minimize length of survey. Respondents were selected randomly from Krishna, East and West Godavari Districts in such a manner that the sample represented the total population as closely as possible (Harlow, 2010) ${ }^{[11]}$. We have also used news papers as a source of as a primary source of data since they too provide relevant information (Tanacković et. al., 2014) ${ }^{[12]}$.

\section{Results and Discussion}

Various activities associated with aquaculture such as fish seed production, harvesting, transportation, marketing, processing, feed production have halted due to nationwide lockdown (Admini, 2020) ${ }^{[13]}$ in spite of being allowed by different governments in India (MHA, 2020) ${ }^{[14]}$. Aquaculture businesses were believed to pursue their activities under conditions of adequate social distancing and sanitation which proved to be difficult (MSSRF, 2020) ${ }^{[15]}$. All these resulted in decreased efficiency, reduced productivity and low turn-out of work force as described in the subsequent sections which ultimately led to dire economic consequences (Jigeesh, 2020) ${ }^{[16]}$

\subsection{Fish Transport}

Absence of transport system has affected the harvest and postharvest sector in fisheries besides lowering seed production activity. India is posed to face fish scarcity in several states because of the nationwide lockdown. The situation is likely to deteriorate because restrictions involved during lock down have derailed movement of fish from Andhra Pradesh to several other states. There was drastic fall in fish supplies by $80 \%$ in most of the markets in northern India. Markets closer to coastal areas and inland fishery farms are getting barely 10$20 \%$ of the fish they usually consume. Although, fish supplies were found to be little better in West Bengal, price of fish has dropped at the wholesale market. Lack of labour, transportation, ice to preserve catch and cold storage facilities has also been a challenge for the fish trade (CGIAR, 2020) [17]. The market in Kolkata has a daily demand of around 550 tons. Despite being the second-largest fish producer after Andhra Pradesh, West Bengal (17.4 lakh tons, annually) has a deficit of 6 lakh tonnes of fish which is being mostly met by Andhra Pradesh (Bandyopadhyay, 2019; Ghosal, 2018) ${ }^{[18,19]}$. Usually, an average of 2,000 tons fish daily was transported from Andhra Pradesh to various parts in India. Only 250 to 300 tons fish was transported daily during lockdown period which computed to be $15.2 \%$ of fish transport from Andhra Pradesh (Fig. 2). Similarly another major fish market, Ghazipur mandi (New Delhi) which trades 900-1000 ton of fish daily was selling only 115-200 tons of fish during lockdown indicating execution of only $22 \%$ of fish sales during April to August, 2020. Restrictions imposed on vehicular movement due to the corona virus outbreak had drastically reduced supply of livestock, poultry, fish by $85 \%$ (Sultan, 2020) ${ }^{[20]}$. Similar trend was recorded in two urban markets in Andhra Pradesh viz., Vijayawada and Eluru wherein fish sales ranged from 8 to $10 \%$ (Fig. 3). Domestic sales and distribution trades significantly happen in urban fish markets because of ample retailing channels that distribute fish to primary markets that are located in villages and semi-urban areas (Alam, 1999) ${ }^{[21]}$. More than 70\% of fish from Andhra Pradesh is sold in urban markets in other states (Seetharaman, 2018) ${ }^{[22] . ~ F i s h ~ c o n s u m p t i o n ~ i n ~ I n d i a ~ i s ~ m o r e ~ i n ~ u r b a n ~ a r e a s ~ i n ~}$ comparison to rural areas (Mandal, 2018; Singh et. al., 2016) [23, 24]. Any barrier that hinders fish transport to urban domestic markets and subsequent distribution to rural markets in India leads to fish scarcity besides suspending crop in fish supplying states like Andhra Pradesh. Out of 0.3 million tons of fish which was expected to be marketed during April to August, only $18.2 \%$ of normal trading was transported to various markets in India. Further implications reveal that 75$80 \%$ of freshwater fish is held out as suspended crop in Andhra Pradesh. It is a difficult proposition to solve, since real harvesting months extend from March to May. Although situation seemed to improve after restoration of usual transport after nationwide lockdown (Sally, 2020) ${ }^{[25]}$, many uncertainties with regard to the duration and severity of the pandemic, a prolonged market downturn is likely to bring several transformations in the aquaculture sector (FAO, 2020) [26].

\subsection{Production Cost \& Farm Gate Price}

Fish sales are taking place $500 \mathrm{MT} /$ day which accounts to $12 \%$ of normal. Initially it was only $240 \mathrm{MT} / \mathrm{day}(5 \%$ of normal) in the month of April. Market trend with regard to sale of different fishes (Fig. 4) revealed that price of Pangasius fish which was sold at INR 76 before lockdown has drastically reduced to INR 64 recording a fall of $15.8 \%$ due to low marketing during lockdown thereby incurring $13.5 \%$ loss by farmers on production cost of INR 76. Similar trend was observed with regard to carps whose market preference has reduced from INR 105 per $\mathrm{kg}$ to INR 92 and recorded 12.4\% reduction and incurring a loss of INR 13 per $\mathrm{kg}$ by carp farmers against a production cost of INR 105. Drastic fall in fish prices was due to absence of retail markets. Retailers find it difficult to travel to the wholesale market in the absence of transport. As a result, fish prices dropped by $15-20 \%$ (Sally, 2020) ${ }^{[25]}$. Live fish retail sales increased by $30 \%$ in periurban areas in Andhra Pradesh due to the closure of the food service industry. Marketing trend with regard to Pacu (Rupchanda) established a stable trend even during lockdown. Consistently, it was sold at price ranging from INR 100 to 95 independent of nationwide lockdown. This could be due to preference of this fish as substitute to catla in states like Tripura, Assam and West Bengal (Uchoi et. al., 2015) ${ }^{[27]}$ as also limited production levels happening at present. Rupchanda farmers marketed it for a gain of INR 10 per $\mathrm{kg}$ earning a profit of $11.8 \%$. White-leg shrimp (Litopenaeus vannamei) recorded lowest price of INR 180 against production cost of INR 220 thus recording $18.2 \%$ loss and loosing INR 45 per kg (Fig. 5). Farmers incurred heavy production costs during 2019-20 due to exorbitantly high cost of DORB which was sold Rs. 20 per kilo through large part of 
the year which was uncommon in previous years.

\subsection{Fish Seed}

Majority of the fish farmers (84\%) in Andhra Pradesh buy fish seed directly from authorized fish hatcheries besides importing various seeds viz., Pacu (Piaractus brachypomus), Pangasius (Pangasianodon hypopthalmus), Chital (Notopterus chitala) from West Bengal (Jayasankar, 2018) [28]. Traders have expressed that interstate transport of fish seed from West Bengal to other states like Andhra Pradesh, Bihar, Jharkhand, Madhya Pradesh and Uttar Pradesh was blocked due to stringent implementation of lockdown, fear of the virus, labour scarcity and shortage of trucks. Although few hatcheries in West Bengal have completed summer breeding of Pangasius, only $10-15 \%$ of seed could be stocked by seed growers before imposing lockdown. Few hatcheries which bred Indian Major Carps have no takers for fish seed due to lockdown (Ghosal, 2020) ${ }^{[29]}$. This will result in huge gap in fish seed demand besides hampering seed stocking for grow-out in July to September. Although, peak breeding of Indian Major Carps usually extend from June to September

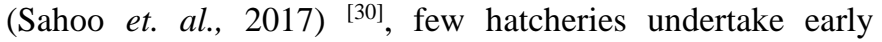
breeding (summer breeding) in April (Ramakrishna et. al., 2013) ${ }^{[31]}$. Fish Seed hatcheries in Andhra Pradesh produced 885 crore carp seed during 2018-19 (DADF, 2019) ${ }^{\text {[32] }}$. Premonsoon fish breeding in Andhra Pradesh yields 10 to $20 \%$ of carp seed amounting to 100 crore fry which is stocked for rearing up to September for raising of stunted seed. Lack of availability of labour fish seed hatcheries in Andhra Pradesh could not resort to summer breeding of carps as also Pangasius (Fig. 6). Although Government exempted aquaculture activities such as hatchery operations, movement of fish seed, feed and workers from lockdown (MHA, 2020; PTI, 2020) [14, 33], aquaculture activities could not gain momentum due to limitations in maintaining social distancing, executing farm operations with minimum workers. Restrictions in movement of labour by local villages due to the nationwide lockdown, transportation of fishes and shrimps is being interrupted by local authorities (Narasimhan, 2020) [34]

\subsection{Farm Repairs and Maintenance}

Normally, farmers undertake repairs to fish ponds and existing machinery during summer. There is severe shortage of technicians for repair and maintenance of farm machinery. Availability of spare parts has become difficult due to lock down of agriculture implements outlets (MSSRF, 2020) ${ }^{[15]}$. Business volume has come down to $7-10 \%$ when compared to normal days. Renovation and digging of new fish ponds has become impossible due to (i) non-availability of excavators and earth movers, (ii) exorbitantly high hiring charges, (iii) limited working hours, (iv) premium price of HSD and (iv) acute shortage of labour. The lockdown that was imposed to arrest the spread of corona virus has severely impacted the viability of machine operations to a minimum of $6-8 \%$ (Raghavendra, 2020) ${ }^{[35]}$. Supply of HSD oil was confined to specific timings leading to increase in demand (MSSRF, 2020) ${ }^{[15]}$ which made it difficult to farmers for obtaining for operating farm engines besides taxes on diesel and petrol were hiked (TNIE, 2020) ${ }^{[36]}$.

\subsection{Farm Labour}

Essentially, a lot of manual labour is involved in fisheries at the time of harvesting as also after the shrimp is harvested and before it is processed. Over $50 \%$ of the workers in fisheries sector are migrants and were not available locally since most of them went to their respective states while local workers were not coming to work because of the restrictions imposed by their respective village heads to check the spread of the pandemic. It is estimated that only $18 \%$ of labour were attending to perform farm operations. Maintaining social distance among workers which could not happen practically has hampered the farm operations in aquaculture. In some districts like East Godavari district, out of total 11,000 workers only about 2,000 (18.5\%) were attending the duty due to restrictions imposed in local villages. Similar situation is prevailing in other aquaculture prime districts viz., Krisha and West Godavari wherein out of 40,000 work force, less than $15 \%$ farm workers are delivering duties. Fish packers are able to transport $20-25 \%$ of vehicles due to shortage of man power. On an average 50 workers are required during harvesting for which farmers find it difficult to obtain even $10 \%$ of requirement (Pradhan, 2020) ${ }^{[37]}$.

Various tasks such as loading and unloading of fish, transport of stock and ice and other jobs that are labour intensive could not be performed. This has resulted in stagnation of 0.2 million tons of fish that remained in ponds un-harvested during nationwide lock down in Andhra Pradesh. Subsequently, this will result in delaying of fish stocking for the next crop. Fortunately, summer in this season has not warranted shortage of water. Water was available in Krishna basin through larger part of the year in total capacity that was allotted to Andhra Pradesh. Otherwise, conditions would have compelled fish farmers to opt for crisis harvesting. Out of 72 shrimp processing units and 35 fish packing units in Andhra Pradesh less than $30 \%$ are operating with less than $20 \%$ of workers during lockdown. Thus, most of them are functioning less than one-third of the installed capacity (Telangana Today, 2020) ${ }^{[38]}$. Over $95 \%$ of the workers in the processing plants are women while majority of them are migrant workers (Jigeesh, 2020) ${ }^{[16]}$. Although, movement of workers involved in aquaculture related operations is permitted by government, but could not be implemented due to restrictions specified under lockdown measures such as social distancing and proper hygiene practices. District authorities have ensured strict enforcement of safety norms (Acharyulu, 2020) ${ }^{[39]}$. Some of the markets in North India were operating with only $1-2 \%$ of workers only (Sally, 2020) ${ }^{[25]}$. Out of 4000 migrant workers in Ghazipur mandi, only 1100 constituting to $27.5 \%$ were available to handle sales proceedings (Jha, 2020) ${ }^{[40]}$. Fishing activity in most of the reservoirs in Andhra Pradesh and Telangana was affected due to labour problem (Jigeesh, 2020) ${ }^{[16]}$. It is estimated that the fisheries sector provides livelihoods to about 16 million fishers and fish farmers at the primary level and almost twice the number along the value chain who were restrained out of pre-harvesting and postharvesting practices (Vohra, 2020) ${ }^{[41]}$. Women, who account for about half of all small scale fish workers were affected badly due to Covid-19 crisis. Fish vendors who are majority being women, could not perform door to door selling activities. These women are often the main income earners for their households (CGIAR, 2020) ${ }^{[17]}$. The lockdown imposed in the March followed by annual fishing ban in mid-April and beyond rendered jobless thousands of fishermen in Andhra Pradesh (Patnaik, 2020) ${ }^{[42]}$.

\subsection{Fish Feed}

Despite the strong demand for meat, dairy, and aquaculture 
products amidst the coronavirus pandemic, the supply chain has witnessed a series of disruptions, which are stopping producers from providing their products in the market. Impact of the pandemic on consumers, is supposed to reduce the demand for animal protein which in turn affect the feed market (Wood, 2020) ${ }^{[43]}$. Fish feed production is also under stress as supply of raw materials like corn, soya, de-oiled rice bran and oil cakes is posing a problem in the absence of road transport (Ghosal, 2020) ${ }^{[29]}$. As a result, the animal feed industry is experiencing higher commodity costs due to limited availability and delayed deliveries (Roembke, 2020) [44].

Small fish and shrimp farmers in Andhra Pradesh integrate their livelihood through combination of agriculture and aquaculture (MSSRF, 2020) ${ }^{[15]}$. They procure inputs like feed, fertilizer and chemicals from the earnings obtained through agriculture or farm labour. However, they are facing financial constraints due to absence of farming operations and unable to feed or resorting to under feed the livestock. Most of the small farmers have extended the culture period due to low scale marketing and incurring heavy costs on feeding the livestock. Trash fish which is used as one of the feed ingredients by small scale fish and crab farmers was not available due to suspension of fishing activity due to nationwide lockdown. Further, shrimp farmers have delayed stocking due to lockdown while fish farmers have suspended crop harvest due to absence of markets. It is estimated that only $15-20 \%$ of summer stocking is happening in Andhra Pradesh as also in other states (Pradhan, 2020) [37]. Subsequently, demand for shrimp and fish feeds was restricted to less than 20\%. Most of the feed plants in Andhra Pradesh which produce 0.1 million tons of feed per month are operating to less than $50 \%$ of production capacities due to lack of man power and stand still transport.

\subsection{Government Intervention}

In a circular to all states and Union territories, the Union Ministry for home affairs has permitted undertaking operations of the fishing (marine and inland)/ aquaculture industry, including feeding \& maintenance, harvesting, processing, packaging, cold chain, sale and marketing, Hatcheries, feed plants, commercial aquaria. Movement of fish/ shrimp and fish products, fish seed/ feed and workers for all these activities (MHA, 2020) ${ }^{[14]}$. This has eased the situation to some extent despite difficulties involved in maintaining social distance and measures for personal and farm hygiene.

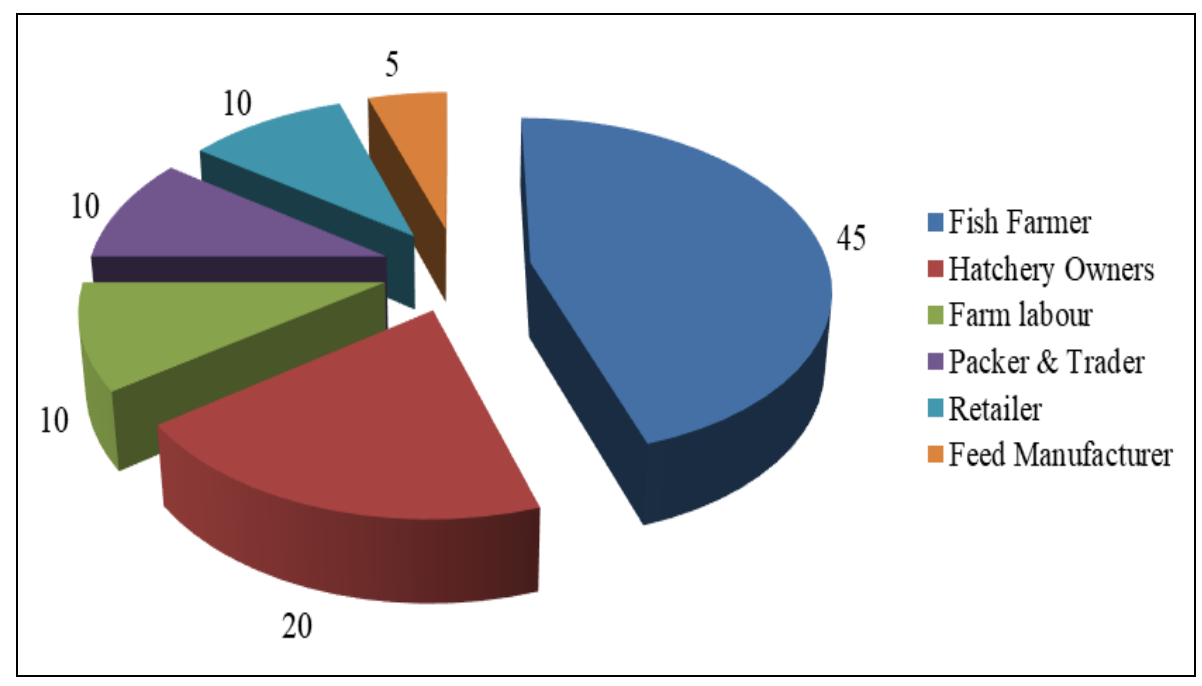

Fig 1: Pie chart showing cross section of respondents participated in e-survey

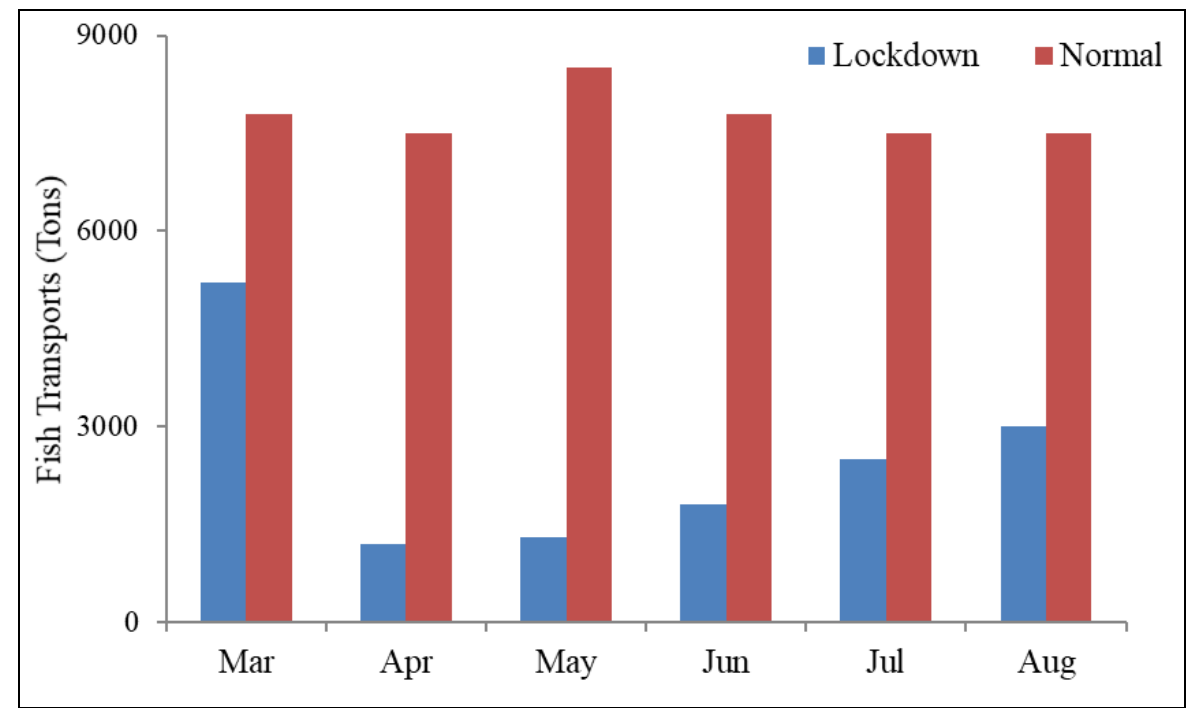

Fig 2: Histogram showing quantum of fish transported from Andhra Pradesh during Nationwide lockdown 


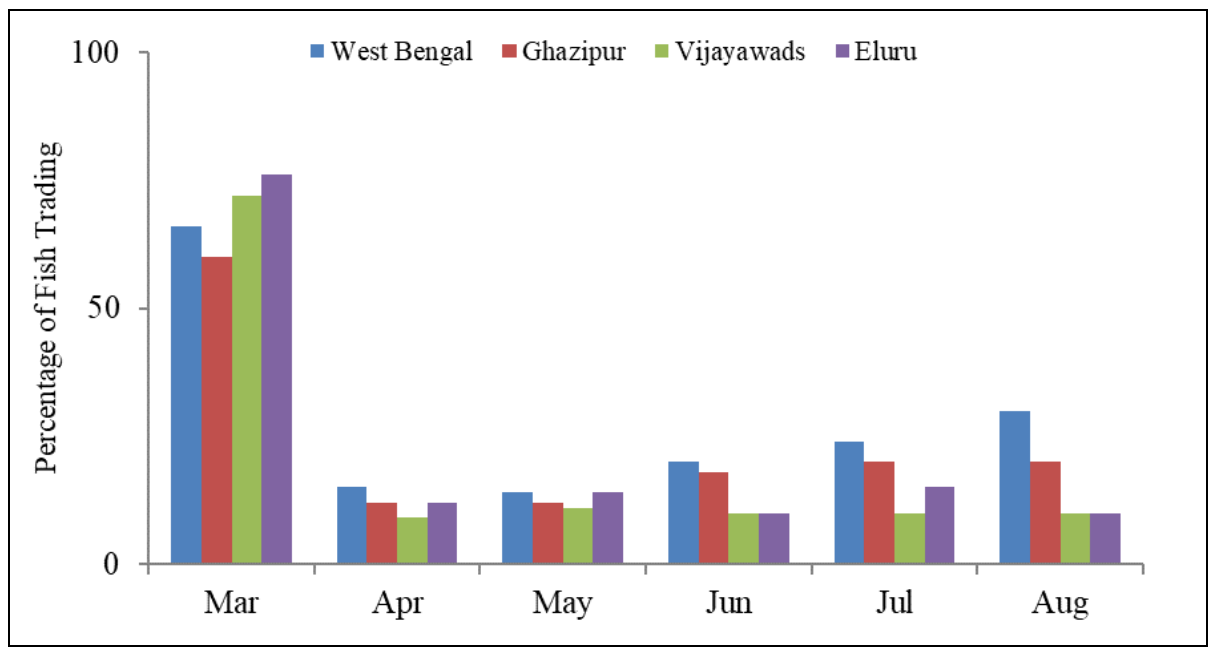

Fig 3: Histogram showing percentage of fish trading in different urban markets during nationwide lockdown

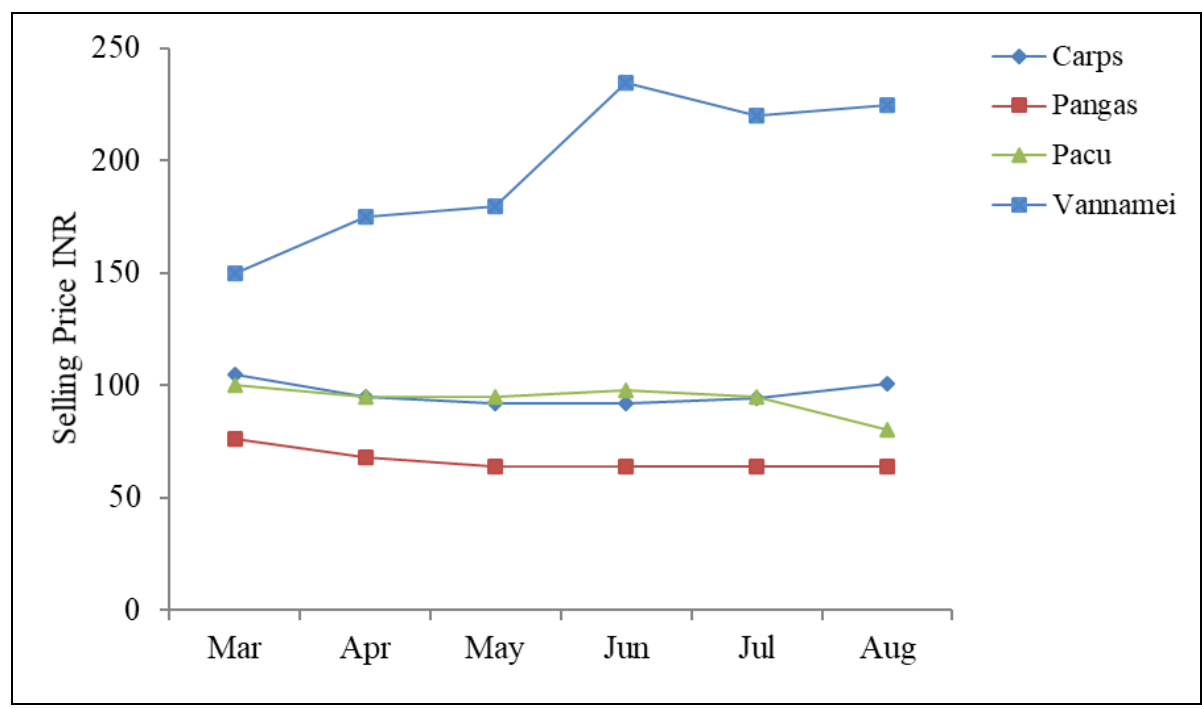

Fig 4: Line drawing showing trend in market price for fish and shrimp during nationwide lockdown period.

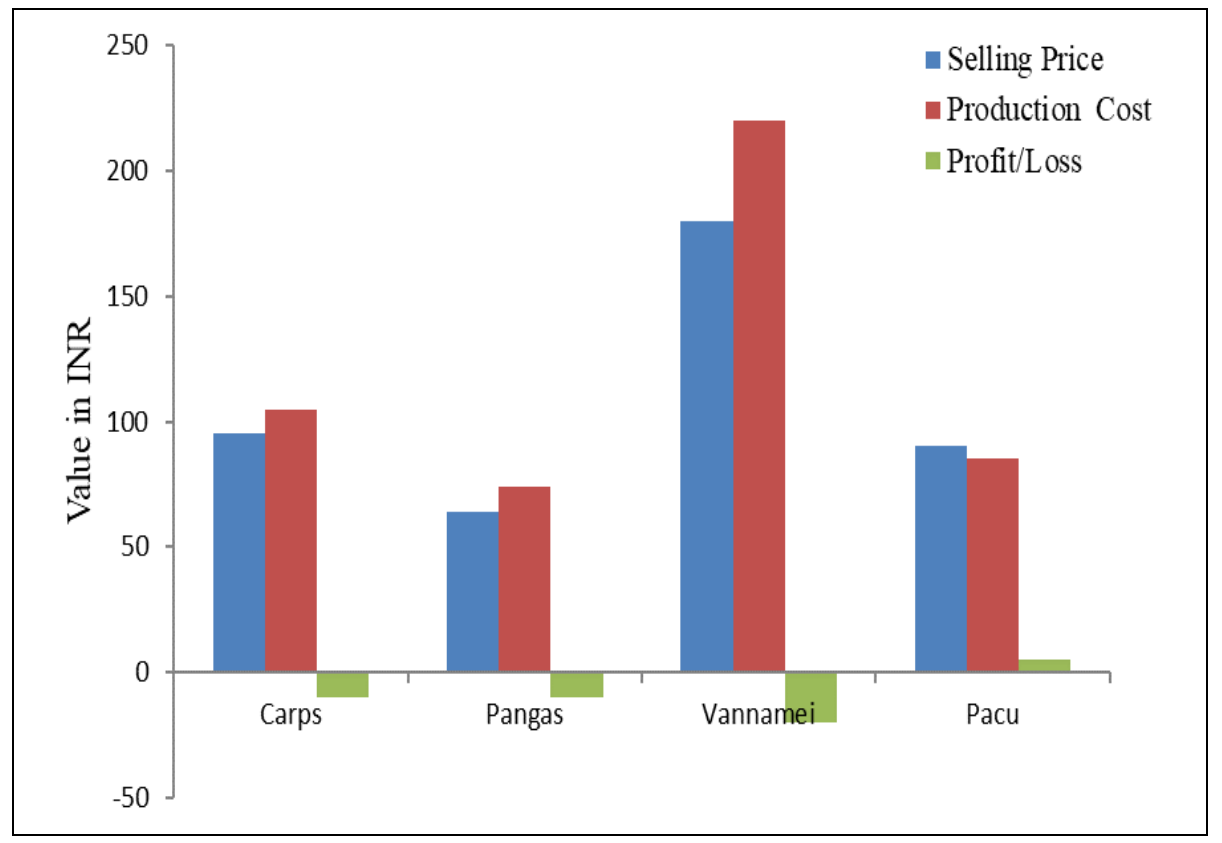

Fig 5: Histogram showing mean selling price and production cost of various fish during nationwide lockdown in Andhra Pradesh. 


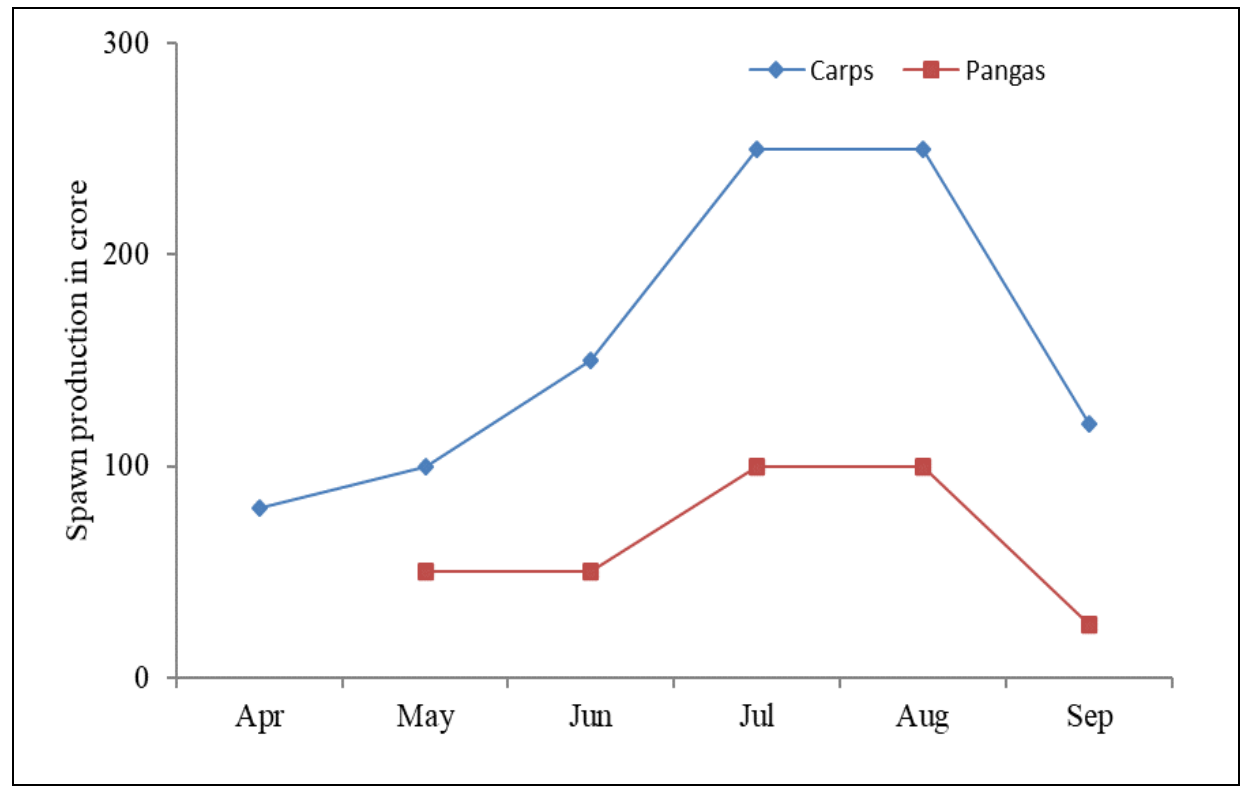

Fig 6: Line drawing showing normal trend for fish seed production in Andhra Pradesh

\section{Conclusion}

Fish transports and loadings recorded increase by $20-30 \%$ in August, 2020 (Fig. 2). Carp prices have increased marginally by $7 \%$ indicating that fish markets in Eastern India are resuming but the farm gate prices of Pangasius and Pacu continued in the lower order causing significant losses to fish farmers because markets in North India have yet to become normal. White-leg shrimp (Litopaeneus vannamei) was fetching a price of INR 225 per kilo due to scarcity of material in the market (Fig. 4). Nationwide lock down has not only projected that aquaculture sector is mainly depending on migratory labour but also warranted the need for skill development in local human resources. It was also highlighted that fish has not really entered village markets. Some governments like West Bengal have realized the necessity for developing rural markets and started selling of fish in rural areas through official vehicles to enhance fish consumption and improving market flow. In spite of such proactive steps, farmers had no other option for the time being, than to cope with the labour problem, movement restrictions, paralyzed supply chains and drastic falling in prices. Nationwide lock down has also highlighted the acute need for improving fish consumption in the country.

\section{Acknowledgments}

Authors express deep sense of gratitude to Dr. J. K. Jena, Deputy Director General (FS), Indian Council of Agriculture Research, New Delhi and Dr. Bindu R. Pillai, Director, ICAR-Central Institute of Freshwater Aquaculture, Bhubaneswar for consistently prompting us to persuade aquaculture scenario in Andhra Pradesh during lockdown period. We are grateful to the stake holders and representatives of aquaculture sector for providing ground level information which helped to us to present real-time situation in this communication. We are thankful to all the authors whose reference material was widely used in compiling the data and formatting discussion.

\section{References}

1. Kumar P, Dey MM, Paraguas F. Fish supply projections by production environments and species types in India. Agricultural Economics Res. Rev. 2006; 19:327-351.
2. Ayyappan S, Krishnan M. Fisheries sector in India: Dimensions of development. Indian Journal of Agricultural Economics, 2004; 59:392-412.

3. Sushmakrishna KS, Cherishya DR, Leela MS. Aquaculture, a replacement of agriculture in Andhra Pradesh, India. Acta Scientific Agriculture, 2019; 3(6):122-124.

4. PIB. Average growth in fish production during 2017-18 stands at $10.14 \%$ with $14 \%$ increase in Inland fisheries. 2018 ,

https://pib.gov.in/PressReleaseIframePage.aspx?PRID=1 585615.

5. Srikanth SG. Andhra stands first in fish production, $\begin{array}{lll}\text { shows } \quad \text { Economic } & \text { Survey. }\end{array}$ https://www.newindianexpress.com/cities/vijayawada/20 20/feb/01/andhra-stands-first-in-fish-production-showseconomic-survey-2097351.html.

6. Keelery S. Fish production volume across Andhra Pradesh India. 2019: 735818, https://www. statista.com/ statistics/735818/fish-production-volume-andhrapradesh-india.

7. Ameen MD. Aquaculture plays vital role in state economy. Hans India, 2018, https://www.thehansindia.com/posts/index/AndhraPradesh/2018-03-09/Aquaculture-plays-vital-role-instate-economy/364695

8. Kumar J. Andhra Pradesh banks on aquaculture for economic growth. Seafood Source, 2018, https://www.seafoodsource.com/news/aquaculture/andhra -pradesh-banks-on-aquaculture-for-economic-growth

9. Andrews D, Nonnecke B, Preece J. Conducting Research on the Internet: Online Survey Design, Development and Implementation Guidelines. Intl. J. Human-Computer Interaction, 2003; 16(2):185-210.

10. Evans JR, Mathur A. The value of online surveys. Internet Res. 2005; 15(2):195-219.

11. Harlow A. Online Surveys-Possibilities, Pitfalls and Practicalities: The Experience Of The Tela Evaluation. Waikato J. Education, 2010; 15(2):95-108.

12. Tanacković SF, Krtalić M, Lacović D. Newspapers as a Research Source: Information Needs and Information Seeking of Humanities Scholars. $80^{\text {th }}$ The World Library 
and Information Congress, 2014, 1-14. https:/www.ifla.org/ files/assets/newspapers/ Geneva_2014/s6-lacovic-en.pdf.

13. Admin TFT. Fish and Aquatic Food Systems COVID-19 Updates: India. 2020, The Fish Site, 5:5. http://blog.worldfishcenter.org/2020/05/covid-19updates-india/

14. MHA-Ministry of Home Affairs. OM No. 40-3/2020DM-I-A 2020, dt. 15 ${ }^{\text {th }}$ April, 2020.

15. MSSRF. COVID impact on aquaculture in Tamil Nadu, Andhra Pradesh and Odisha, 2020, MSSRF / PB / 2020 / 05 / April 2020. https://www.mssrf.org/sites/ default/files/ 05\%20Aquaculture.pdf.

16. Jigeesh AM. Distressed fisheries sector demands immediate support. Business online, 2020, https://www.thehindubusinessline.com/economy/agribusiness/distressed-fisheries-sector-demands-immediatesupport/article31332857.ece..

17. CGIAR. Fish and Aquatic Food Systems COVID-19 Updates: India. 2020, 19: https:// fish.cgiar.org/newsupdates/news/fish-and-aquatic-food-systems-covid-19updates India.

18. Bandyopadhyay K. Kolkata: Demand-supply gap leaves dear fish dearer. Times of India, 2019; 68, https://timesofindia.indiatimes.com/city/kolkata/demandsupply-gap-leaves-dear-fish-dearer/

article show/68880715.

19. Ghosal S. West Bengal to meet fish production target. Economic Times, 2018; 8:28. https://economictimes.indiatimes.com/news/economy/agr iculture/west-bengal-to-meet-fish-production-targetchandra-nath-sinha-minister-forfisheries/articleshow/65580797.

20. Sultan P. Delhi's meat, poultry stock depleting fast amid coronavirus lockdown. NIE, 2020, https://www.newindianexpress.com/cities/delhi/2020/mar /30/delhis-meat-poultry-stock-deple ting-fast-amidcoronavirus-lockdown-2123294.html.

21. Alam A. Production, accessibility and consumption patterns of aquaculture products in Bangladesh. FAO, 2019; 3:28, http://www.fao.org/3/y2876e0d.htm\#Top of Page.

22. Seetharaman G. Fish farms to produce nearly two third of India's fish supply by 2030. Economic Times, 2018, https://economictimes.indiatimes.com/news/economy/agr iculture/ fish-farms-to-produce-two- thirds-of-indias-fishsupply.

23. Mandal N. Study on Fish demand and supply and engagement of private sector in the fish sub sector in Jharkhand. jslps.org/wp-content/uploads/2018/02/FinalFishery-Report.pdf

24. Singh R, Pandey PK, Salim S, Krishnan M. Evolving fisheries business in India with GIS. Geospatial World. 2016, https://www.geospatialworld.net/article/evolvingfisheries-business-in-india-with-gis/

25. Sally M. Lockdown blues: Meat na mila re mann ka. Economic Times, 2020; 75:81-86. https://economictimes. indiatimes.com/industry/cons-products/food/lockdownblues-meat-na-mila-re-mann-ka/ article show $/ 75088164 . \mathrm{cms}$ ?from $=\mathrm{mdr}$.

26. FAO. Novel Coronavirus (COVID-19) impact on fisheries and aquaculture. FAO, 2020, http://www.fao.org/2019-ncov/q-and-a/impact-onfisheries-and-aquaculture/en/
27. Uchoi R, Shyama S, Golandaj A, Sreenath VR, Yadav RP. Growth potential of Pacu, Piaractus brachypomus in different Culture Approach. Res. J. Animal, Vet. and Fishery Sci., 2018; 3(6):8-13.

28. Jayasankar P. Review Present status of freshwater aquaculture in India - A review. Indian J. Fish. 2018; 65(4):157-165. DOI: 10.21077/ijf.2018.65.4.81300-20.

29. Ghosal S. Slow movement of fish seeds from Bengal due to lockdown to impact fish production in the country. Economic Times, 2020; 15:20. https://economictimes. indiatimes.com/ news/economy/ agriculture/ slowmovement-of-fish-seeds-from-bengal-due-to-lockdownto-impact-fish-production-in-the-country.

30. Sahoo PR, Ananth PN, Nandi S, Sundaray JK, Barik NK, Jayasankar P. Early Breeding and Seed Production of Indian major Carps: Attributes of the Innovation from an Adaptive Trial. Curr Agri Research, 2017; 5(1). doi: http://dx.doi.org/10.12944/CARJ.5.1.07.

31. Ramakrishna R, Shipton TA, Hasan MR. Feeding and feed management of Indian major carps in Andhra Pradesh, India. FAO Fisheries and Aquaculture Technical 2013; 578:101.

32. DADF. Hand book on Fishery Statistics. Department of Fisheries Ministry of Fisheries, Animal Husbandry and Dairying New Delhi, 2019, 190.

33. PTI. Corona virus-Fishing, marine aquaculture activities exempted from lockdown. 2020, https://www.thehindu.com/news/national/coronavirusfishing-marine-aquaculture-activities-exempted-fromlockdown/article31312757.ece

34. Narasimhan TE. Rough times for fisheries to get worse after Covid-19 lockdown is lifted. 2020, Business Standard, $\quad 4: 20 . \quad$ https://www.businessstandard.com/article/economy-policy/rough-times-forfisheries-to-get-worse-after-covid-19-lockdown-is-lifted120040400841_1.html.

35. Raghavendra $\bar{V}$. Andhra Pradesh to give incentives to lockdown-hit industries. 2020, https://www.thehindu.com/news/national/andhrapradesh/andhra-pradesh-to-give- incentive to-lockdownhit-industries/article31599246.ece.

36. TNIE. Shell out more for petrol and diesel in Andhra Pradesh from today. 2020, https://www.newindianexpress.com/states/andhrapradesh/2020/mar/01/shell-out-more-for-petrol-anddiesel-in-andhra-pradesh-from-today-2110599.html.

37. Pradhan P. Shrimp farmers at their wits' end. 2020, https://smartagripost.com/shrimp-farmers-at-their-witsend/

38. Telangana Today. Andhra Pradesh's aquaculture sector in jeopardy. 2020, https://telangana today.com/andhrapradeshs-aquaculture-sector-in-jeopardy.

39. Acharyulu, SNCN. Centre amends lockdown for fishing, aquaculture. Deccan Chronicle, 2020; 4:12. https://www.deccanchronicle.com/nation/in-other-news/ 120420/centre- amends-lockdown-for-fishingaquaculture.html.

40. Jha AK. Stranded Bihar migrants in Ghazipur fish mandi seek to return home, 2020, https://www.aninews.in/news/national/generalnews/stranded-bihar-migrants-in-ghazipur-fish- mandiseek-to-return-home20200506193547/

41. Vohra S. India's lockdown has put 16 million fisherfolk out of business. Here's how they're coping. Scroll.in. 
2020. https://scroll.in/article/959062/indias-lockdownhas-put-16-million-fisherfolk-out-of-business-heres-howtheyre-coping.

42. Patnaik S. Lockdown turns out to be a boon for Vizag fishermen. The Hindu, 2020, https://www. thehindu.com/ news/national/andhra-pradesh/lockdown-turns-out-to-bea-boon-for-vizag-fishermen/article31798531.ece.

43. Wood L. COVID-19 Impact on Feed Market by Application (Poultry, Swine, and Aquaculture), Ingredient \& Additive Type (Amino Acids, Phosphates, Vitamins, Minerals, Commodity Ingredients, Phytogenics, and Probiotics) and Region. 2020, Global Forecast to, 2021.

44. Roembke J. Four ways COVID-19 may impact feed production. Feed Strategy Magazine, 2020, 3:13. https://www.feedstrategy.com/blog/4-ways-covid-19may-impact-feed-production. 